\title{
DIE KULTURELE VERDRAG TUSSEN NEDERLAND EN DIE UNIE.
}

\author{
I. VERKLARING VAN DIE PERSAFDELING VAN DIE \\ NEDERLANDSE AMBASSADE, PRETORIA.
}

"Wij zijn verheugd over dit verdrag en verwachten er veel van", het prof. dr. D. B. Bosman, die toenmalige Ambassadeur van SuidAfrika, by die ondertekening van die kulturele verdrag tussen Nederland en die Unie verklaar; en tereg, want hierdie kulturele verdrag is die offisiële bevestiging van 'n kontak wat, ondanks historiese lotswisselinge, steeds tussen Suid-Afrika en Nederland bestaan het.

In 'n tafelrede het die Ambassadeur van die Nederlande in die Unie, mnr. Jan van den Berg, eendag gesê: „Tyd en afstand het in die loop van die jare geknaag aan die besembos van Nederlands-Suid-Afrikaanse betrekkinge-daar was tye waarop die ou stammetjie 'so amper middeldeur' was. In albei lande het daar egter'n lewende en werksame kern van welwillendheid oorgebly wat gewoeker het om die kosbare stamverband te handhaaf en tot nuwe vrugbaarheid op te wek".

Dit is dan wat ons hoop dat deur die kulturele verdrag tussen die Unie en Suid-Afrika tot stand sal kom. Dit word nie ontken nie dat daar, ook na die oorgawe van die Kaap aan Engeland, 'n voortdurende kontak tussen Suid-Afrika en Nederland bly bestaan het. Daarvan getuig byvoorbeeld die pogings van jhr. dr. F. W. A. Beelaerts van Blokland om die Kaap in die dae van die Groot Trek van Nederlandse literatuur te voorsien en die aanwesigheid van die „Kaapse studente” wat Klikspaan in sy „Studententypen" (1841) noem.

Reeds van 1884 af verleen Nederland elke jaar beurse aan Suid-Afrikaanse studente wat in Nederland wil kom studeer. Die deure van skole en universiteite het in Nederland altyd vir Suid-Afrikaners oopgestaan, en Suid-Afrikaanse sertifikate op die gebied van onderwys het in Nederland altyd erkenning gevind. Dit was vir 'n Suid-Afrikaner, waar dit skool en universiteit betref, nog nooit nodig om in Nederland iets oor te doen wat hy in Suid-Afrika reeds met sukses voltooi het nie. In party opsigte was Nederland teenoor Suid-Afrikaners selfs bereid tot 'n tegemoetkomendheid by die stel van eise op onderwysgebied, ook by eksamens, wat dit aan eie landskinders nie gegee het nie. 


\section{S.A. was nog nie altyd so tegemoetkomend as Nederland nie.}

Dieselfde kan nog nie in elke opsig gesê word wat betref die Nederlander in Suid-Afrika nie. Dis te hope dat die kultuurverdrag daartoe sal bydra dat ' $n$ bevredigende oplossing op die gebied van die erkenning van die mediese grade gevind word. Tans word byvoorbeeld 'n Nederlandse dokter met ' $n$ volledige kliniese opleiding verplig om in Suid-Afrika drie volledige kliniese jare aan die universiteit oor te doen voor hy die kwalifikasie kan verwerf om as praktiserende geneesheer op te tree.

Ook die Afrikaanse taalwetenskappe, die letterkunde, die godgeleerdheid, die regswetenskap en die geskiedenisbeskouing het in die verlecle voortdurend elkeen op sy beurt uit Nederland geput.

En omgekeerd het wat op genoemde gebiede in Suid-Afrika gebeur het, tot 'n inspirasie geword vir Nederland.

'n Verdrag is 'n tweesydige affêre. Dit kan nie alles van die een kant kom nie.

So was dit dat 'n kulturele verdrag eintlik voorberei is deur die spontane aksies van die bevolking van albei lande. Hoekom het dit dan nie eerder gekom tot 'n offisiële reêling daarvan nie?

Van die oomblik af dat Suid-Afrika selfstandig as 'n inter-nasionaal erkende staat aan die verkeer met ander state deelgeneem het, het daar van die kant van Nederland die wens bestaan om met Suid-Afrika kulturele betrekkings te reël, soos Nederland dit gedoen het met België, Frankryk, Engeland en ander state.

So lank as Suid-Afrika nie internasionaal erken was nie, kon dit nie gebeur nie.

Maar ook nadat die internasionale erkenning van Suid-Afrika deur die instelling van gesantskappe oor en weer plaasgevind het, was daar nog moeilikhede. Dit wil sê: in Suid-Afrika moet rekening gehou word met die feit dat die Afrikaanse kultuur nie die erkende kultuur is van die hele bevolking van Suid-Afrika nie maar slegs van die een deel, die Afrikaanssprekendes.

Die strekking van die verdrag met Nederland moes so wees dat dit, net soos die strekking van 'n moontlike ooreenkomstige verstandhouding met 
Engeland, sou beantwoord aan die wense van albei blanke bevolkingsgroepe ten opsigte van die eie groep sowel as ten opsigte van die ander groep.

\section{Die verdrag is minder sprekend as wat dit kon gewees het.}

Die gevolg is dat die verdrag, as mens sy inhoud nagaan, baie minder sprekend is as wat dit sou kon gewees het. Die belangrike onderdele van die kultuur van die Afrikaner wat wortel in die kultuur van Nederland, word nie eers by name genoem nie. Die taal van die Afrikaner, sy letterkunde, sy godsdiens en sy kerklike lewe, die Romeins-Hollandse reg, almal belangrike kultuuruitings wat Nederland tot agtergrond het en die kern vorm van die Afrikaanse kultuur, word in die verdrag nie eers by hul naam genoem nie.

Die kultuurverdrag van Suid-Afrika met Nederland het dus ' $n$ verdrag geword wat hom, wat die inhoud betref, in geen enkele opsig onderskei van 'n kulturele verdrag van Suid-Afrika of van Nederland met enige ander willekeurige land waarmee dit hierdie belangrike kultuurgoedere nie gemeen het nie.

Dis derhalwe nie die inhoud van die verdrag wat dit moet doen nie, maar wel die toespassing wat nou sal moet begin.

\section{Die toepassing moet nou begin.}

Op die gebied van die werklike uitlewing van die kulturele kontak tussen Nederland en Suid-Afrika bestaan, soos bo genoem, reeds veel, en dit bestaan reeds baie jare, sonder dat daartoe 'n verdrag nodig was.

Sedert 'n paar jaar stel ook die Suid-Afrikaanse Regering beurse vir Nederlandse studente beskikbaar met die oog op studie in Suid-Afrika. Daar was nog altyd 'n oorvloed van applikante, en die feite bewys dat studie in Suid-Afrika vir menige jong Nederlander ' $n$ begerenswaardige verruiming van sy geestelike horison sal word.

Van Nederland uit is eers aan die Universiteit van Pretoria (1929) en daarna aan die Universiteit van Kaapstad (1950) 'n leerstoel in die Nederlandse kultuurgeskiedenis gestig. Daarenbowe word die Nederlandse Kultuurhistoriese Instituut in Pretoria, uit Nederlandse inisiatief gebore, uit Nederland voortdurend van materiaal voorsien.

Daarteenoor is in Nederland aan die Universiteit van Amsterdar: Jie leerstoel in die taal, letterkunde, geskiedenis en instellings van r":e Afrika- 
ner in die lewe geroep, waaraan die Suid-Afrikaanse Regering nou geldelike steun verleen, terwyl daar ook 'n jaarlikse subsidie vir die aankoop van materiaal gegee word.

Verder was daar die jaarlikse besoeke van Nederlandse geleerdes aan Suid-Afrika, wat in 1936 begin het, deur die oorlog onderbreek is maar na die oorlog weer voortgesit is.

Terwyl daar nou dus op die gebied van die kulturele betrekkings al heelwat tot stand gekom het, sal nou met die toepassing van die verdrag daardie betrekkings langs amptelike kanale gelei word, en dan moet langs wat reeds bestaan, nuwe dinge in die lewe geroep word.

Aan albei kante, in Nederland sowel as in Suid-Afrika, is kommissies van regeringsweë benoem, aan wie die taak opgedra is om dit uit te voer. Hiervoor is geld nodig, en die eerste stap wat nou aan albei kante sal moet gedoen word, is natuurlik om na te gaan hoeveel beskikbaar gestel kan word vir die uitvoering van die verdrag, buite en behalwe wat in die verlede reeds jaarliks op die begroting uitgetrek is.

'n Verdrag is ' $n$ tweesydige affêre. Dit kan nie alles van die een kant kom nie. Nederland en Suid-Afrika sal in redelike verhouding tot wat hulle hul kan veroorloof en tot wat die ander man doen, geld ter beskikking moet stel. Agterbly van die een op hierdie gebied sal tot vertraging van die voortgang van die ander lei.

Die beste beleid is om stap vir stap vorentoe te gaan.

Die gebied van werksaamheid is amper eindeloos en die moontlikheid onuitputlik. Dit sal waarskynlik die beste beleid blyk om stap vir stap vorentoe te gaan en nie oorhaastig te word nie, sodat mislukkings en teleurstellings vermy kan word, en om die werksaamhede wat die beste aanpas by wat reeds tot stand gebring is, die eerste aan die beurt te laat kom. Wetenskap, onderwys-ook middelbare en laer onderwysen die beeldende kunste is die mees voor die hand liggende gebiede waarop sal moet gewerk word.

Uit die aard van die saak sal die taak van die betrokke kommissics verlig word wanneer hulle by hul werk gehelp word deur die steun en raad van mense en liggame wat dit eens is met die doel van die verdrag, d.w.s. met die bevordering van die kulturele betrekkinge tussen die twee lande. Dit sal noodsaaklikerwys baie geld kos, en die verantwoordelikheid vir die beste besteding van die gelde rus in die eerste plek op die skouers van albei kommissies. 
Daar bestaan geen beter middel om hierdie doel te dien as die persoonlike kontak nie. Dis te hope dat die verdere ontwikkeling sal meebring dat 'n stelsel van gereelde uitwisseling tot stand kom. Dis baie belangrik, veral omdat by die uitvoering 'n groot beswaar wat daarmee gepaard gaan om die afstand te oorwin.

Die persoonlike kontak sal egter nooit vir die menigte van betekenis kan wees nie. Dit moet op 'n ander manier bereik word: deur die boek en die tydskrif, deur draadloos en weldra deur televisie, deur die luister na konserte en die kyk na tentoonstellings.

Veel wat albei volke tot opbou van eie innerlike wese mekaar kan sê, sal nie sommer dadelik aan die beurt kan kom nie. Dit sal van die beskikbare geld afhang, van die mense wat geroep sal word om te bring en te haal; en dit sal afhang van die aard van die onderdeel van die kultuur of dit binne die perke van die moontlikheid toelaat om van die een land na die ander oorgebring te word om daar sy heilsame werk van mekaar beter te verstaan en mekaar te verryk deur uitwisseling van geesteskrag te verrig.

Noudat ons staan aan die begin van die uitvoering van 'n verdrag wat sulke wye perspektiewe open, pas dit om die hoop uit te spreek dat albei lande in die toekoms ook altyd die mense sal oplewer wat bereid is en in staat is om hulle in diens te stel van 'n doel wat vir altwee lande so hoog en so lewewekkend is.

Albei lande koester hoe verwagtinge van die verdrag; wanneer dit uitgevoer word in 'n gees van vertroue en vriendskap, sal dit die middel wees waardeur die kultuur van die een land die ander in steeds groter mate sal kan verryk.

\section{OPMERKINGE VAN PROF. DR. G. DEKKER.}

Graag voldoen ek aan die versoek van die Redaksie om enkele opınerkinge te maak n.a.v. hierdie stuk oor 'n gebeurtenis van belang vir die kulturele betrekkinge tussen Nederland en Suid-Afrika.

Veel kommentaar vereis hierdie stuk nie. Ek kan my heeltemal daarmee vereenselwig. Dis seker onnodig om nog weer uit te wei oor die belang van noue Dietse, met name Nederlands-Afrikaanse, kulturele betrekkinge. Dieselfde geld ook vir die nouer getrokke kring van diegene in Nederland en Suid-Afrika wat die beginsels waarvoor „Koers" staan, tot 
die grondslag van hulle lewe en wetenskap het. Daardie beginsels is in ons land oorgeplant deur Jan van Riebeeck toe hy hier die Gereformeerde religie gevestig het. Daardie plantjie het sy lewenskrag geopenbaar deur in die nuwe bodemgesteldheid en klimaat 'n eie Afrikaanse karakter te openbaar, maar gedurige wisselwerking met die ou stamland bly dwingende vereiste, sowel vir ons, as, na my beskeie mening, vir Nederland.

Afgesien van die wedersydse verryking deur die geskrewe woord is sedert die bevryding in intellektuele kringe in Potchefstroom gereeld en met dankbaarheid die stimulerende invloed ondervind van persoonlike kontak met geëerde oorsese gaste. Ek dink hier o.a. aan die besoek van vooraanstaande digters soos Adriaan Roland Holst, wat vanuit sy heel ander sfeer so insiggewend oor Totius geskryf het, J. C. Bloem, die digtergreleerde Donkersloot, die historikus Prof. van Winter; verder aan ons geesverwante: die professore Waterink, Dooyeweerd en Van der Horst, ook aan die vrugbare werksaamheid in ons midde van prof. Bavinck. Van ons kant gaan daar gedurig studente en dosente na Nederland vir verdere studie. Ek dink hier ook aan die besoek aan Nederland van prof. J. C. van Rooy, Rektor van die Universiteit, om 'n eredoktoraat te ontvang van die Vrije Universiteit.

Die vrug van hierdie kontakte kom nie tot openbaring in luidrugtige geesdrif nie, maar in dieper werkende beinvloeding, besieling wat vir albei partye winste bring van verruiming, verdieping, besinning op gemeenskaplike ideaal en roepingsbesef.

Die om begryplike redes vaag gestelde kulturele verdrag bring dus nie iets nuuts nie maar is belangrik as 'n erkenning van staatsweë van die noodsaaklikheid van hierdie kontakte, erkenning ook van die werk wat, grotendeels in die stilte, in die verlede gedoen is, o.a. deur die Genootskap Nederland-Suid-Afrika, waarvan daar in Potchefstroom ' $n$ afdeling bestaan. Dis belangrik ook om die moontlikhede van verdere uitbou van hierdie strewe wat dit binne die bereik stel.

Die strekking van die verdrag is nie om wat tot nog toe deur persone of groepe nagestreef en bereik is, nou oor te dra aan 'n staatskommissie nie-dit moet aanspoor tot voortsetting van wat met inspanning bereik is en nou die stempel van offisiële erkenning verkry het.

Waar met die bespreking van bo aangehaalde stuk die hele saak van die kulturelc betrekkinge tussen Nederlanders en Afrikaners tog eintlik ter sprake is, wil ek eindig met die vraag te stel of ons nie moet oppas nie om 
1441

te eensydig die blik onrsee te wend na wetenskaplike en artistieke figure en kringe en of daar nie meer gedoen kan en moet word nie om die groot getalle Nederlandse immigrante in ons land behulpsaam te wees om gouer deel te kan hê aan die Afrikaner se sosiale lewe en sy kulturele en geestelike lewe en strewe. Die Nederlandse immigrant word 'n aanwins vir ons volk as hy sy Dietse bewustheid uitleef in Afrikaanse verband, in Afrikaanse vorm. Voor hy dit kan doen, moet hy egter eers sekere moeilikhede oorwin, wat ons nie moet onderskat nie: hy moet in die vir hom vreemde, aanvanklik miskien enigsins naïef aandoende, Afrikaanse vorme die geestelike, die kulturele inhoud ontdek-dan sal hy die gemeenskaplike aanvoel. Dis ons Dietse, ons Christelike plig, dis ons eie belang om hom hierin behulpsaam te wees. 